\title{
DINAMIKA PERAN SEKTOR PERIKANAN DALAM PEREKONOMIAN INDONESIA: Analisis Input-Output 1990-2005
}

\author{
Tajerin ${ }^{1}$ \\ ${ }^{1}$ Peneliti pada Balai Besar Riset Sosial Ekonomi Kelautan dan Perikanan \\ JI. KS. Tubun Petamburan VI, Jakarta 10260 \\ Telp. 021 53650162/Fax. 02153650159
}

\begin{abstract}
ABSTRAK
Kajian ini bertujuan untuk menganalisis dinamika peran sektor perikanan dalam perekonomian Indonesia, khususnya dalam output perekonomian, pendapatan rumah tangga dan penyerapan tenaga kerja. Data yang digunakan adalah data sekunder yang diperoleh dari buku Tabel Input-Output (I-O) Tahun 1990, 1995, 2000 dan 2005. Analisis data dilakukan dengan menggunakan pendekatan model (I-O) melalui perolehan nilai koefisien angka pengganda. Hasil analisis menunjukkan bahwa secara umum peran sektor perikanan dalam perekonomian Indonesia menunjukkan kecenderungan peningkatan pada era sebelum, transisi dan setelah berdiri Departemen Kelautan dan Perikanan (DKP). Namun secara spesifik, peran sub sektor perikanan sekunder lebih besar dalam pembentukan output perekonomian dan pendapatan rumah tangga dibanding sub sektor perikanan primer. Sementara dalam penyerapan tenaga kerja, peran sub sektor perikanan primer lebih besar dibanding sub sektor perikanan sekunder, khususnya pada era sebelum berdiri DKP, namun kemudian lebih besar peran sub sektor perikanan sekunder pada era transisi dan setelah berdiri DKP.
\end{abstract}

Kata Kunci: Analisis Input-Output, Perikanan, Perekonomian Indonesia.

\section{Abstract: Dynamic of Fisheries Sector's Role in the Indonesian Economy: Input-Output Analysis 1990-2005. By: Tajerin}

This study was focused on analyzing the dynamic of fisheries sector's role in the Indonesian economy, especially on economic output, household income and labor absorbsion. Secondary data used in this study were obtained from Input-Output (I-O) Table of 1990, 1995, 2000 and 2005 published by the Central Bureau of Statistics Indonesia, and later on analyzed through I-O approach and its multiplier coefficients result. Results showed that in general, the role of the fisheries sectors in Indonesian economy has tended to increase- be it before. During the transition and after the estabilishment of the Ministry of Marine Affairs and Fisheries (MMAF) era. Specifically, the role of secondary fisheries sub sector was more dominant than the primary fisheries sub sector in the formation of economy's output. As for the labor absorbsion, the role of primary fisheries sub sector was more dominant than secondary fisheries sub sector, especially before the estabilishment of MMAF; however, this dominance went a vice versa during the transition and after the estabilishment of MMAF.

Keywords: Input-Output Analysis, Fisheries, Indonesian Economy. 


\section{PENDAHULUAN}

Terpaan gelombang dampak krisis keuangan global semakin kuat akhir-akhir ini menyebabkan kondisi perekonomian bangsa Indonesia menjadi semakin berat dan rumit. Sementara upaya untuk keluar dari tekanan krisis ekonomi yang mendahuluinya belum sepenuhnya berhasil.

Untuk keluar dari kondisi krisis tersebut, dari sudut pandang pembangunan ekonomi diperlukan peningkatan peran nyata berbagai sektor sehingga diperoleh pertumbuhan ekonomi yang berkelanjutan.

Dalam era globalisasi dan perdagangan bebas, pertumbuhan ekonomi tersebut dapat diwujudkan jika bangsa tersebut mampu menciptakan sumber pertumbuhan baru dan memelihara atau meningkatkan efisiensi sumber pertumbuhan yang ada. Pertumbuhan ekonomi dalam hal ini mengacu pada produksi barang dan jasa yang berdaya saing tinggi dan dibangun atas keunggulan kompetitif dan komparatif yang berbasiskan sumberdaya alam serta menerapkan ilmu pengetahuan dan teknologi. Dengan paradigma tersebut, seharusnya dengan memanfaatkan kekayaan potensi sumberdaya alam yang ada, pembangunan perikanan akan mampu berperan nyata menolong bangsa ini keluar dari krisis ekonomi (Dahuri,et al. 2001). Salah satu indikasinya adalah pada saat Indonesia tengah menghadapi terpaan badai krisis ekonomi sepanjang tahun 1997-1998 yang ditandai dengan jatuhnya nilai tukar rupiah terhadap dolar, sub sektor perikanan justru menampilkan kinerja pertumbuhan yang positif. Pada tahun tersebut ekspor perikanan mencapai US\$ 1,90 milyar dan impor mencapai US\$ 129,41 juta atau terdapat surplus perdagangan mencapai US\$ 1,78 milyar. Dari sisi neraca perdagangan pada saat krisis ekonomi (tahun 1997), sektor perikanan masih mengalami surplus dari tahun sebelumnya (Kusumastanto, 2002).

Peluang pengembangan investasi di sektor perikanan juga menunjukkan prospek yang baik. Hal ini terlihat dari besarnya nilai
ICOR (Incremental Capital Output Ratio) dari setiap bagian dari sub sektor perikanan. Secara agregat nilai ICOR untuk sub sektor perikanan sebesar 3,42 (dengan rincian perikanan tangkap sebesar 2,80 dan perikanan budidaya air payau sebesar 3,95 ) (Kusumastanto, 2002).

Pembangunan perikanan selama tiga dasa warsa terakhir diposisikan sebagai "pinggiran" (peripheral sector) dalam pembangunan ekonomi nasional (Kusumastanto, 2002). Dengan posisi semacam ini sektor perikanan bukan menjadi "arus utama" (main-stream) dalam kebijakan pembangunan ekonomi Indonesia. Kondisi ini menjadi ironis mengingat hampir $70 \%$ wilayah Indonesia merupakan wilayah pesisir dan lautan dengan potensi ekonomi yang sangat besar serta berada pada posisi geopolitik yang penting, yakni Lautan Pasifik dan Lautan Hindia sebagai kawasan paling dominan dalam pencaturan dunia baik secara ekonomi dan politik di dunia.

Dalam perkembangannya kemudian, "wajah" sektor perikanan berubah dan mampu menunjukkan eksistensinya dalam perekonomian Indonesia, terutama setelah mendapatkan momentum baru dalam rangkaian pembangunan ekonomi Indonesia, yaitu dengan dibentuknya Departemen Eksplorasi Laut dan Perikanan (DELP) dan terakhir menjadi Departemen Kelautan dan Perikanan (DKP). Sejak berdirinya DKP, pertumbuhan pembangunan perikanan melaju dengan cukup tinggi. Hal ini antara lain dapat dilihat dari indikator pertumbuhan Produk Domestik Bruto (PDB) sektor perikanan sejak tahun 2000 hingga 2004 yang terus meningkat dengan rata-rata kenaikan per tahun sebesar $17,07 \%$, dan rata-rata kenaikan PDB perikanan ini secara relatif lebih tinggi dibanding dengan sektor pertanian lainnya bahkan dengan PDB nasional (BPS, 20002004 dalam DKP, 2005a).

Dari tataran ekonomi politik, dengan terbentuknya DKP, sektor perikanan telah mendapatkan kekuatan dan keberhasilannya dalam proses perubahan yang mendasar di 
Tabel 1. Produk Domestik Bruto (PDB) Sub Sektor Perikanan dan Sub Sektor Lainnya dari Sektor Pertanian Berdasarkan Harga Berlaku, Tahun 2000-2005 (Milyar Rp.).

Table 1. Groos Domestic Product (GDP) of Fisheries Sub Sector and Other Sub Sector from Agricultural Sector at the Current Market Prices, at of 2000-2005 (Rp.Billion).

\begin{tabular}{|c|c|c|c|c|c|c|}
\hline \multirow{2}{*}{$\begin{array}{l}\text { Sub Sektor/ } \\
\text { Sub Sectors }\end{array}$} & \multicolumn{6}{|c|}{ Tahun/Year } \\
\hline & 2000 & 2001 & 2002 & 2003 & 2004 & 2005 \\
\hline $\begin{array}{l}\text { - Perikanan/ Fisheries } \\
\text { - Peternakan /Livestock }\end{array}$ & $\begin{array}{l}29.510 \\
27.035\end{array}$ & $\begin{array}{l}35.221 \\
30.467\end{array}$ & $\begin{array}{l}39.775 \\
35.122\end{array}$ & $\begin{array}{l}44.794 \\
39.043\end{array}$ & $\begin{array}{l}55.266 \\
49.122\end{array}$ & $\begin{array}{l}44.614 \\
39.236\end{array}$ \\
\hline - Perkebunan/Estate crope & e 33.745 & 37.372 & 42.010 & 47.050 & 57.419 & 49.827 \\
\hline $\begin{array}{l}\text { - Tanaman Pangan/ } \\
\text { Food Crops }\end{array}$ & 112.661 & 126.065 & 141.411 & 146.350 & 170.912 & 146.537 \\
\hline - Kehutanan/Forestry & 14.948 & 15.597 & 16.953 & 19.002 & 21.717 & 17.172 \\
\hline Nasional/National & 1.264 .919 & 1.467 .655 & 1.610 .565 & 1.786 .691 & 2.303 .031 & 1.007 .307 \\
\hline
\end{tabular}

Sumber/Source: BPS (2005) dalam DKP (2005 $)$; BPS (2006).

Tabel 2. Pertumbuhan Produk Domestik Bruto (PDB) Sub Sektor Perikanan dan Sub Sektor Lainnya dari Sektor Pertanian Berdasarkan Harga Berlaku, Tahun 20002005 (Milyar Rp.).

Table 2. Growth of Gross Domestic Product (GDP) of Fisheries Sub Sector and Other Sub Sector from Agricultural Sector at Current Market Prices, at of 2000-2005 (Rp.Billion ).

\begin{tabular}{|c|c|c|c|c|c|c|c|}
\hline \multirow{2}{*}{$\begin{array}{l}\text { Sub Sektor/ } \\
\text { Sub Sectors }\end{array}$} & \multicolumn{5}{|c|}{ Tahun/Year } & \multirow{2}{*}{$\begin{array}{c}\text { Rataan/ } \\
\text { Average } \\
2000-2004 \\
(\%)\end{array}$} & \multirow{2}{*}{$\begin{array}{c}\text { Rataan/ } \\
\text { Average } \\
2000-2005 \\
(\%)\end{array}$} \\
\hline & $\begin{array}{c}2000- \\
2001\end{array}$ & $\begin{array}{l}2001- \\
2002\end{array}$ & $\begin{array}{l}2002- \\
2003\end{array}$ & $\begin{array}{l}2003- \\
2004\end{array}$ & $\begin{array}{l}2004- \\
2005\end{array}$ & & \\
\hline - Perikanan/ Fisheries & 19,35 & 12,93 & 12,62 & 23,38 & $-19,27$ & 17,07 & 11,01 \\
\hline - Peternakan / Livestock & 12,69 & 15,28 & 11,16 & 25,82 & $-20,13$ & 16,24 & 8,97 \\
\hline - Perkebunan/Estate Crope & 10,75 & 12,41 & 12,00 & 22,04 & $-13,22$ & 14,30 & 8,79 \\
\hline $\begin{array}{l}\text { - Tanaman Pangan/ } \\
\text { Food Crops }\end{array}$ & 11,90 & 12,17 & 3,49 & 16,78 & $-14,26$ & 11,09 & 6,02 \\
\hline - Kehutanan/Forestry & 4,34 & 8,69 & 12,09 & 14,29 & $-20,93$ & 9,85 & 3,70 \\
\hline Nasional/National & 16,03 & 9,74 & 10,94 & 28,90 & $-56,26$ & 16,04 & 1,87 \\
\hline
\end{tabular}

Sumber/Source: BPS (2005) dalam DKP (2005ª); BPS ( 2006).

tingkat kebijakan nasional. Semestinya dengan terbentuknya DKP tersebut, peran sektor perikanan dalam perekonomian Indonesia mengalami peningkatan secara nyata, tidak saja dalam output perekonomian ataupun dalam PDB-nya (sebagaimana ditunjukkan dalam Tabel 1 dan Tabel 2) tetapi juga perannya dalam pendapatan rumah tangga dan penyerapan tenaga kerja. Diduga bahwa perkembangan peran sektor perikanan tersebut khususnya dalam pendapatan dan tenaga kerja tidak sebaik seperti perannya dalam output perekonomian. Disinyalir hal ini karena peran sektor perikanan tersebut masih dihadapkan oleh banyak permasalahan pembangunan yang menyebabkan perikanan menjadi sektor yang tertinggal. Ketertinggalan tersebut dilihat dari rendahnya tingkat sumberdaya dan tingkat penguasaan teknologi, tingkat kemiskinan dan keterbelakangan nelayan yang paling parah dibanding kelompok sosial lainnya, daya serap kesempatan kerja tinggi namun produktivitas ekonominya rendah, minat investasi terutama 
dalam skala menengah dan besar relatif kurang karena belum dipahami berbagai aspek seperti resiko dan besarnya kapital yang dibutuhkan (Kusumastanto, 2001).

Berkaitan dengan permasalahan tersebut, kajian ini dilakukan untuk mengetahui sejauh mana peran sektor perikanan, khususnya dalam peningkatan output perekonomian, pendapatan rumah tangga dan penyerapan tenaga kerja. Hasil kajian ini diharapkan dapat memberikan masukan untuk penyempurnaan kebijakan dan strategi serta program pembangunan perikanan ke depan.

\section{METODOLOGI}

\section{Data dan Sumber Data}

Untuk dapat merekam peran sektor perikanan pada era sebelum, transisi dan setelah berdiri digunakan data sekunder dari buku Tabel Input-Ouput (I-O) Tahun 1990, 1995, 2000 dan 2005 yang disusun oleh Badan Pusat Statistik (1994, 1999, 2004 dan 2007) menurut klasifikasi matrik yang besar, yaitu: 161 x 161 sektor untuk tahun 1995; 172 x 172 sektor untuk tahun 1995; dan 175 x 175 sektor untuk tahun 2000 dan 2005. Penggunaan Tabel I-O tersebut dimaksudkan agar dapat menggambarkan kondisi pada era sebelum berdiri DKP (1990-1995), era transisi berdiri DKP (1995-2000) dan era setelah berdiri DKP (2000-2005).

Era sebelum berdiri DKP (1990-1995) tidak dimaksudkan bahwa pada era tersebut sektor perikanan belum eksis, karena sebenarnya pada era tersebut sektor perikanan berada dalam naungan Direktorat Jenderal Perikanan di bawah Departemen Pertanian. Pada era tersebut sektor perikanan telah melakukan kegiatan produksi yang outputnya telah dikonsumsi oleh rumah tangga, dan menerima sejumlah investasi, mendapatkan anggaran rutin dan pembangunannya serta melakukan kegiatan ekspor dan impor. Dalam kajian ini, posisi era ini dimaksudkan sebagai pembanding bagi era berikutnya, khususnya yang dilihat berdasarkan besaran angka pengganda (multiplier effect) sehingga bila kemudian dalam analisis diperoleh perubahan yang menurun (negatif) dibandingkan era berikutnya, maka hal ini tidak berarti bahwa sektor perikanan tersebut telah mengalami kinerja yang menurun (buruk) karena hal ini saja justru diperoleh besaran nilai-nilai indikator sektor perikanan (seperti produksi) yang meningkat (positif). Selain itu, perubahan angka pengganda yang terjadi pada era tersebut, misalnya bernilai negatif tidak dimaksudkan meniadakan peran pemerintah dalam era tersebut.

Masing-masing Tabel I-O yang digunakan merupakan Tabel I-O transaksi domestik atas dasar harga produsen, dimana setiap nilai transaksi hanya mencakup barang dan jasa domestik dan dinilai atas dasar harga produsen. Mengingat ukuran matrik masingmasing Tabel I-O tidak sama, pada tahap awal dilakukan konversi klasifikasi matriks Tabel I-O 1995, 2000 dan 2005 ke dalam klasifikasi terendah (161 x 161 sektor). Selanjutnya setelah semua Tabel I-O yang digunakan dalam kajian ini menjadi sama ukuran matriksnya, dilakukan pengklasifikasian kembali dengan cara mengagregasi beberapa sektor menjadi klasifikasi matriks $9 \times 9$ sektor, seperti tertera pada Tabel 3.

\section{Metode Analisis}

Analisis peran sektor perikanan dalam perekonomian Indonesia (khususnya perannya dalam peningkatan output produksi, peningkatan pendapatan rumah tangga dan penyerapan tenaga kerja), dalam kajian ini digunakan analisis pengganda berdasarkan pendekatan model Input-Output (I-O). Angka pengganda dalam hal ini berupa suatu koefisien yang menyatakan kelipatan dampak langsung dan tidak langsung dari peningkatan permintaan akhir suatu sektor sebesar satu unit terhadap produksi total semua sektor (Miller dan Blair, 1985). Pada intinya, analisis angka pengganda berupaya melihat apa yang 


\section{Tabel3. Pengklasifikasian Sektor dari Tabel Input-Output Dinamika Peran Sektor Perikanan dalam Perekonomian Indonesia, Tahun 1990-2005}

Table 3. Sector Clasificasion of Input-Output Table in the Dynamic of Role of the Fisheries Sectorin Indonesian Economy, at of 1990-2005.

\begin{tabular}{|c|c|c|c|c|}
\hline \multirow{2}{*}{$\begin{array}{l}\text { Sektor/ } \\
\text { Sector }\end{array}$} & \multirow{2}{*}{$\begin{array}{l}\text { Deskripsi// } \\
\text { Deskription }\end{array}$} & \multicolumn{3}{|c|}{$\begin{array}{l}\text { Sektor dalam Tabel Input -Output/ } \\
\text { Sectors within Input-Output Table }\end{array}$} \\
\hline & & 1990 & 1995 & 2000 dan 2005 \\
\hline \multirow[t]{2}{*}{1.} & $\begin{array}{l}\text { Pertanian non perikanan/ Non fisheries } \\
\text { agriculture }\end{array}$ & $1-28$ & $1-31$ & $1-30$ \\
\hline & Perikanan primer/ Primary fisheries: & & & \\
\hline 2. & $\begin{array}{l}\text { - Perikanan laut dan hasil perairan laut } \\
\text { lainnya/ Marine fisheries and other } \\
\text { marine prducts }\end{array}$ & 29 & $32 ; 34 L^{*)}$ & $31 ; 33 L^{* * *)}$ \\
\hline 3. & $\begin{array}{l}\text { - Perikanan darat dan hasil perairan laut } \\
\text { lainnya/ Inland fisheries other marine } \\
\text { prducts }\end{array}$ & 30 & $33 ; 34 L^{* *)}$ & $32 ; 33 L^{* * * *)}$ \\
\hline \multirow[t]{2}{*}{4.} & $\begin{array}{l}\text { Pertambangan dan penggalian/ Mining } \\
\text { and quarry }\end{array}$ & $32-34$ & $36-48$ & $35-48$ \\
\hline & $\begin{array}{l}\text { Perikanan sekunder/ secondary } \\
\text { fisheries }\end{array}$ & 31 & 53 & 53 \\
\hline 5. & $\begin{array}{l}\text { - Industri pengeringan dan } \\
\text { penggaraman ikan dan biota perairan } \\
\text { lainnya/ Fish drying and salted } \\
\text { industries }\end{array}$ & 48 & 54 & 54 \\
\hline 6. & $\begin{array}{l}\text { - Industri pengolahan dan pengawetan } \\
\text { ikan dan biota perairan lainnya/ } \\
\text { Processing and preserving fish } \\
\text { industries }\end{array}$ & $47-48$ & $49-52$ & $49-52$ \\
\hline 7. & $\begin{array}{l}\text { Industri pengolahan hasil pertanian non } \\
\text { perikanan/ Agriculture non fisheries } \\
\text { processing industries }\end{array}$ & $49-83$ & $55-91$ & $55-93$ \\
\hline 8. & $\begin{array}{l}\text { Industri pengolahan lainnya/ Other } \\
\text { processing industries }\end{array}$ & $84-131$ & $92-139$ & $94-141$ \\
\hline 9. & $\begin{array}{l}\text { Jasa-jasa dan lainnya/ Services and } \\
\text { others }\end{array}$ & 132161 & $35 ; 140-172$ & $34 ; 142-175$ \\
\hline
\end{tabular}

Keterangan/ Remaks:

*) Proporsi output sektor 34 (udang) untuk sektor 29 sebesar $54,1 \%$ berasal dari udang hasil tangkapan di laut pada tahun 1995 (BPS, 2004b)/ Output proportion of sector 34 (shrimp) for sector 29 is $54,1 \%$ from marine capture in 1995 (BPS, 2004b)

**) Proporsi output sektor 34 (udang) untuk sektor 30 sebesar 49,9\% berasal dari udang hasil tangkapan di laut pada tahun 1995 (BPS, 2004b)/ Output proportion of sector 34 (shrimp) for sector 30 is 49,9\% from marine capture in 1995 (BPS, 2004b)

***) Proporsi output sektor 33 (udang) untuk sektor 31 sebesar $54,5 \%$ berasal dari udang hasil tangkapan di laut pada tahun 2000 (BPS, 2004b) dan sebesar 39,02\% pada tahun 2005 (DKP, 2007) / Output proportion of sector 33 (shrimp) for sector 31 is 54,5\% from marine capture in 2000 (BPS, 2004b) and 39,02\% in 2005 (DKP, 2007)

****) Proporsi output sektor 33 (udang) untuk sektor 32 sebesar $45,5 \%$ berasal dari udang hasil tangkapan di laut pada tahun 2000 (BPS, 2004b) dan sebesar 60,98\% pada tahun 2005/ Output proportion of sector 33 (shrimp) for sector 32 is 45,5\% from marine capture in 1995 (BPS, 2004b) and 60,98\% in 2005(DKP, 2007) 
terjadi terhadap variabel-variabel endogen tertentu, apabila terjadi perubahan variablevariabel eksogen, seperti permintaan akhir di dalam perekonomian (Perserikatan BangsaBangsa, 2007; Nazara, 2005).

Terkait dengan penggunaan analisis pengganda, dalam model input output dikenal pengganda tipe I dan tipe II. Bila sektor rumah tangga dianggap eksogenus, yang berarti transaksi input antara dengan ukuran $\mathrm{n} \times \mathrm{n}$, sehingga diperoleh matriks koefisien input terbuka, $A=\left[a_{i j}\right]$. Berdasarkan invers matriks $A$ atau $(I-A)^{-1}$, dapat dihitung pengganda tipe I, yang hanya menunjukkan hubungan langsung dan tidak langsung antar sektor dalam perekonomian. Namun bila sektor rumah tangga tersebut dianggap endogenus (dimasukkan dalam tabel transaksi) dengan menambahkan satu baris berupa pendapatan rumah tangga dan satu kolom berupa pengeluaran rumah tangga, sehingga ukuran matriks menjadi $[(n+1) \times(n+1)]$ dan kemudian dapat diperoleh tabel koefisien input tertutup atau matriks $B=\left[b_{i j}\right]$. Selanjutnya berdasarkan invers matrik $B$ atau $(I-B)^{-1}$ dapat dihitung pengganda tipe II yang menunjukkan hubungan langsung dan tidak langsung serta dampak induksi (West, 1992; Miller dan Blair, 1985).

Dalam kajian ini, penghitungan angka pengganda dibatasi hanya pada pengganda Tipe I yang diberlakukan pada tiga hal utama yang menjadi fokus perhatian dalam analisis angka pengganda ini, yaitu: pengganda output sektor-sektor produksi, pengganda pendapatan rumah tangga, dan pengganda penyerapan tenaga kerja. Oleh karena itu, dalam kajian analisis pengganda tersebut terdiri dari angka pengganda output, angka pengganda pendapatan rumah tangga dan angka pengganda penyerapan tenaga kerja (Miler dan Blair, 1985; Nazara, 2005). Secara rinci masing-masing angka pengganda tersebut diuraikan sebagai berikut:

\section{(1) Angka Pengganda Output,}

Angka pengganda output suatu sektor $j$
$\left(O_{j}\right)$ merupakan kenaikan nilai total output atau produksi yang dihasilkan oleh semua sektor dalam perekonomian untuk memenuhi (atau akibat) adanya perubahan satu unit permintaan akhir suatu sektor $j$ tersebut, atau dapat dirumuskan sebagai:

$$
O_{j}=\sum_{i=1}^{n} \alpha_{i j}
$$

\section{(2) Angka Pengganda Pendapatan Rumah Tangga,}

Angka pengganda pendapatan dari suatu sektor $j\left(H_{j}\right)$ juga sering disebut dengan efek pendapatan (income effect) dari model I-O. Nilai angka penganda pendapatan rumah tangga sektor $j$ menunjukkan jumlah pendapatan rumah tangga total yang tercipta akibat adanya tambahan satu unit permintaan akhir (final demand) di sektor $j$ tersebut, atau dapat dirumuskan sebagai:

$$
H_{j}=\frac{\sum_{i=1}^{n} h_{n+1, j} \alpha_{i j}}{h_{n+1, j}}
$$

dimana $h_{n+1, j}$ adalah proporsi upah atau gaji yang diperlukan untuk memproduksi satu unit output sektor yang bersangkutan.

\section{(3) Angka Pengganda Tenaga Kerja,}

Angka pengganda tenaga kerja $\left(E_{j}\right)$ atau disebut juga dengan efek lapangan pekerjaan (employment effect) merupakan efek total dari perubahan lapangan pekerjaan di perekonomian akibat adanya satu unit perubahan permintaan akhir di suatu sektor tertentu, atau dapat dirumuskan sebagai:

$$
E_{j}=\frac{\sum_{i=1}^{n} e_{n+1, j} \alpha_{i j}}{e_{n+1, j}}
$$

dimana $e_{n+1, j}$ adalah proporsi tenaga kerja yang diperlukan untuk memproduksi satu unit output sektor yang bersangkutan. 


\section{HASIL DAN PEMBAHASAN}

\section{Peranan Sektor Perikanan dalam Output Produksi}

Dari Tabel 4 terlihat bahwa besarnya angka pengganda output rata-rata keseluruhan sektor pada awalnya menurun sebesar $18,12 \%$, yaitu dari 1,903 pada tahun 1990 menjadi 1,558 pada tahun 1995, kemudian meningkat sebesar $1,28 \%$ dengan angka pengganda sebesar 1,578 pada tahun 2000 , dan selanjutnya meningkat lagi sebesar $1,58 \%$ dengan angka pengganda sebesar 1,603 pada tahun 2005 .

Tabel4. Rataan Angka Pengganda Output Sektor Perikanan dan Keseluruhan Sektor Ekonomi di Indonesia, Tahun 1990-2005.

Table 4. Average Multiplier Output of Fisheries and All Economic Sectors in Indonesia, at of 1990-2005.

\begin{tabular}{|c|c|c|c|c|c|c|c|}
\hline \multirow[b]{2}{*}{ Sektor/ Sectors } & \multicolumn{4}{|c|}{ Tahun/Year } & \multicolumn{3}{|c|}{ Perubahan (\%)/Changes (\%) } \\
\hline & 1990 & 1995 & 2000 & 2005 & $\begin{array}{c}1990- \\
1995 \\
\text { (ESDKP) }\end{array}$ & $\begin{array}{c}1995- \\
2000 \\
(\text { ERDKP) }\end{array}$ & $\begin{array}{c}2000- \\
2005 \\
\text { (ETDKP) }\end{array}$ \\
\hline $\begin{array}{l}\text { 1. Perikanan primer/ } \\
\text { Primary sectors: }\end{array}$ & 1,527 & 1,280 & 1,302 & 1,272 & $-16,18$ & 1,72 & $-2,30$ \\
\hline $\begin{array}{l}\text { - Perikanan laut / } \\
\text { Marine fisheries }\end{array}$ & 1,665 & 1,367 & 1,323 & 1,241 & $-17,90$ & $-3,22$ & $-6,20$ \\
\hline $\begin{array}{l}\text { - Perikanan darat / } \\
\text { Inland fisheries }\end{array}$ & 1,388 & 1,193 & 1,281 & 1,304 & $-14,05$ & 7,38 & 1,80 \\
\hline $\begin{array}{l}\text { 2. Perikanan sekunder/ } \\
\text { Secondary sectors: }\end{array}$ & 2,666 & 1,981 & 2,017 & 2,043 & $-25,69$ & 1,82 & 1,29 \\
\hline $\begin{array}{l}\text { - Industri pengeringan } \\
\text { dan penggaraman } \\
\text { ikan/Dried and salted } \\
\text { fish industries }\end{array}$ & 2,106 & 1,736 & 1,881 & 2,521 & $-17,57$ & 8,37 & 34,02 \\
\hline $\begin{array}{l}\text { - Industri pengolahan } \\
\text { dan pengawetan ikan/ } \\
\text { Processing and } \\
\text { preserving fish industrie }\end{array}$ & 3,226 & 2,125 & 2,152 & 1,565 & $-34,13$ & 1,27 & $-27,28$ \\
\hline 3. Perikanan/ Fisheries ${ }^{\star}$ & 2,097 & 1,631 & 1,660 & 1,658 & $-20,93$ & 1,77 & $-0,51$ \\
\hline $\begin{array}{l}\text { 4. Keseluruhan sektor } / \\
\left.\text { Total sectors }{ }^{* *}\right)\end{array}$ & 1,903 & 1,558 & 1,578 & 1,603 & $-18,12$ & 1,28 & 1,58 \\
\hline
\end{tabular}

Sumber: Hasil Pengolahan Data Tabel Input Output Tahun 1990, 1995, 2000 dan 2005/

Sources: Processed Results of the Input-Output Table at of 1990, 1995, 2000 and 2005

Keterangan/ Remaks:

ESDKP = Era sebelum berdiri Departemen Kelautan dan Perikanan/ Before establisment of the Ministry Marine Affairs and Fisheries

ERDKP = Era transisi berdiri Departemen Kelautan dan Perikanan/ Transition establisment of the Ministry Marine Affairs and Fisheries

ETDKP = Era setelah berdiri Departemen Kelautan dan Perikanan/ After establisment of the Ministry Marine Affairs and Fisheries

*) Rataan angka pengganda dari perikanan primer dan perikanan sekunder/ Average of primary and secondary fisheris multiplier.

${ }^{* *)}$ Rataan angka pengganda dari seluruh sektor (hasil penghitungan selengkapnya tertera pada lampiran Tabel 5, 6, 7 Dan 8)/ Average of total sector multiplier (completed calculating yield at apendix of Tables 5, 6, 7 And 8). 
Sementara itu, angka pengganda output sektor perikanan pada era sebelum berdiri DKP (ESDKP) periode 1990-1995 menunjukkan kecenderungan angka pengganda output yang menurun sebesar 20,93\%, yaitu dari 2,097 pada tahun 1990 menjadi 1,631 pada tahun 1995. Kemudian meningkat pada era transisi berdiri DKP (ERDKP) periode 1995-2000 sebesar 1,77\% dengan angka pengganda sebesar 1,660 pada tahun 2000 , dan selanjutnya pada era setelah berdiri DKP (ETDKP) periode 20002005 menurun sebesar $0,51 \%$ dengan angka pengganda sebesar 1,658 pada tahun 2005 (Tabel 2 dan Gambar 1).

Angka pengganda output sektor perikanan pada era sebelum berdiri DKP (ESDKP) periode 1990-1995 menurun (negatif) sebesar 20,93\% (sebagaimana ditunjukkan pada Tabel 4 dan Gambar 1 tidak (bukan) berarti bahwa sektor perikanan tersebut telah mengalami kinerja yang menurun (buruk). Hal ini karena perubahan yang menurun (negatif) tersebut adalah terjadi dalam hal angka pengganda (multiplier effect) dari output yang dihasilkan dari kegiatan produksi di sektor perikanan (bukan besaran dari output itu sendiri). Dengan kata lain, bahwa penurunan angka pengganda output sektor perikanan pada era sebelum berdiri DKP (ESDKP) tersebut, menunjukkan perannya dalam peningkatan output bagi keseluruhan sektor dalam perekonomian Indonesia selama periode 1990-1995 yang menurun, dan bukan berarti bahwa angka pengganda untuk masing-masing tahun tersebut (1990 dan 1995) adalah negatif. Hal ini dapat dilihat dalam Tabel 4, dimana angka pengganda output sektor perikanan tersebut adalah positif, yaitu pada tahun 1990 sebesar 1,527 dan pada tahun 1995 sebesar 1,280. Dengan demikian penurunan angka

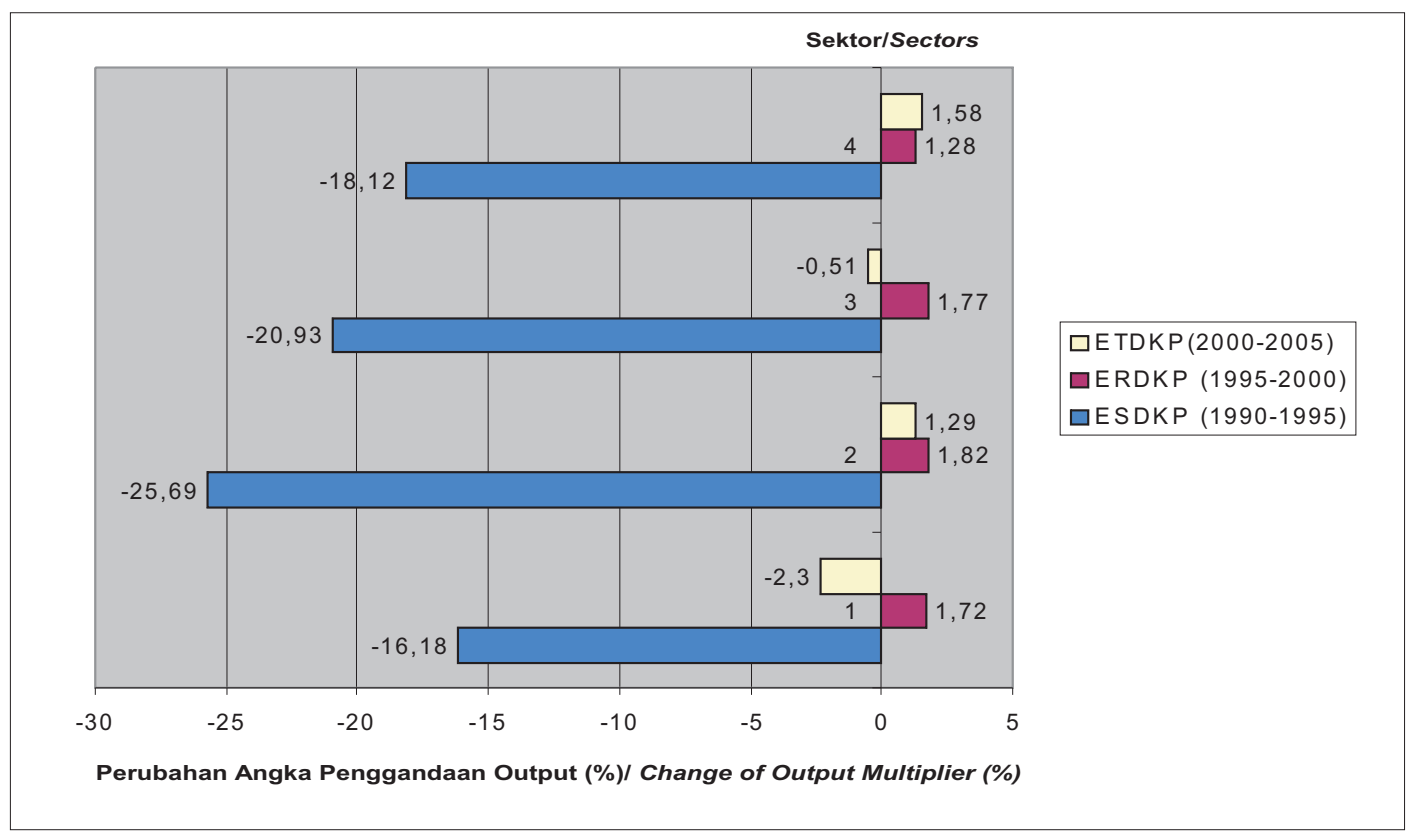

Gambar 1. Dinamika Perubahan Angka Pengganda Output Produksi dari Sektor Perikanan Indonesia, Selama ESDKP (1990-1995), ERDKP (1995-2000) dan ETDKP (20002005).

Figure 1: Dynamic Change in Multiplier Output of the Indonesia Fisheries Sector During ESDKP(1990-1995), ERDKP(1995-2000) and ETDKP(2000-2005). 
Keterangan/Remarks

$(1)=$ Sub sektor perikanan primer (perikanan tangkap laut dan perikanan budidaya)/Primary fisheries sector (marine capture and aquaculture fisheries)

$(2)=$ Sub sektor perikanan sekunder (industri pengeringan dan penggaraman ikan dan industri pengolahan dan pengawetan ikan)/Secondary fisheries sector (drying and salting processing and preserving)

$(3)=$ Rataan sektor perikanan (perikanan primer dan perikanan sekunder)/Avarage of fisheries sector (primary fisheries and secondary fisheries)

$(4)=$ Rataan keseluruhan sektor dan perekonomian Indonesia/Avarage of all sectors in Indonesian economy.

pengganda output sektor perikanan tersebut adalah tidak berarti meniadakan kontribusi pemerintah melalui Direktorat Jenderal Perikanan (di bawah Departemen pertanian) selama periode 1990 hingga 1995 tersebut.

Selanjutnya, besaran angka pengganda tersebut (Tabel 4 dan Gambar 1), menunjukkan bahwa setiap peningkatan satu juta rupiah permintaan akhir (konsumsi rumah tangga, investasi swasta, pengeluaran pemerintah dan ekspor) di seluruh sektor dalam perekonomian nasional akan menyebabkan peningkatan output total produksi senilai 1,903 juta rupiah pada tahun 1990, senilai 1,558 juta rupiah pada tahun 1995, senilai 1,578 juta rupiah pada tahun 2000 dan senilai 1,603 juta rupiah pada tahun 2005. Sedangkan untuk setiap peningkatan satu juta rupiah permintaan akhir di sektor perikanan akan menyebabkan peningkatan output produksi senilai 2,097 juta rupiah pada tahun 1990, senilai 1,631 juta rupiah pada tahun 1995, senilai 1,660 pada tahun 2000 dan senilai 1,658 juta rupiah pada tahun 2005.

Kecenderungan serupa dialami pula oleh sub sektor perikanan primer (perikanan darat dan perikanan laut) maupun sub sektor perikanan sekunder (industri pengeringan dan penggaraman ikan dan industri pengolahan dan pengawetan ikan). Sejak tahun 1990 hingga 1995, pengganda output sub sektor perikanan primer turun sebesar $16,18 \%$, yaitu dari nilai koefisien sebesar 1,527 menjadi sebesar 1,280. Demikian pula dengan pengganda output sub sektor perikanan sekunder yang turun sebesar $25,69 \%$, yaitu dari nilai angka pengganda sebesar 2,666 menjadi sebesar 1,981. Pada selang waktu tersebut, setiap peningkatan satu juta rupiah permintaan akhir (konsumsi rumah tangga, investasi swasta, pengeluaran pemerintah dan ekspor) di sub sektor perikanan primer dan perikanan sekunder masing-masing akan menyebabkan peningkatan output total produksi senilai 1,527 juta rupiah pada tahun 1990 menjadi senilai 1,280 juta rupiah pada tahun 1990; dan senilai 2,666 juta rupiah pada tahun 1995 menjadi sebesar 1,981 juta rupiah.

Selanjutnya pada periode tahun 19952000 , pengganda output kedua sub sektor tersebut (perikanan primer dan perikanan sekunder) mengalami peningkatan masingmasing sebesar $1,72 \%$ dan $1,82 \%$, yaitu dengan nilai angka pengganda output sebesar 1,280 pada tahun 1995 menjadi sebesar 1,938 pada tahun 2000 untuk sub sektor perikanan primer, dan untuk sub sektor perikanan sekunder sebesar 1,981 pada tahun 1995 menjadi sebesar 2,017 pada tahun 2000. Sedangkan pada periode tahun 2000-2005, angka pengganda output kedua sub sektor tersebut justru mengalami kecenderungan berbeda, yaitu untuk sub sektor perikanan primer terjadi penurunan (sebesar 2,30\%), sebaliknya untuk sub sektor perikanan sekunder terjadi peningkatan (sebesar $1,82 \%)$.

Apabila dilihat lebih rinci untuk level bagian sub sektor, kecenderungan (pola perubahan) serupa hanya dialami oleh bagian sub sektor perikanan sekunder baik untuk industri pengeringan dan penggaraman ikan 
maupun industri pengolahan dan pengawetan ikan, dimana masing-masing mengalami penurunan pengganda output dari sebesar 2,106 dan 3,226 pada tahun 1990 menjadi sebesar 1,736 dan sebesar 2,125 pada tahun 1995. Kemudian masing-masing pada tahun 2000 mengalami peningkatan dibanding tahun 1995 menjadi sebesar 1,881 dan 2,152. Sedangkan pada tahun 2005, kedua bagian sub sektor perikanan sekunder tesebut memiliki kecenderungan yang berbeda bila dibandingkan dengan periode sebelumnya (tahun 2000), yaitu untuk industri pengeringan dan penggaraman ikan mengalami kenaikan menjadi sebesar 2,521, dan sebaliknya untuk industri pengolahan dan pengawetan ikan justru mengalami penurunan menjadi sebesar 1,565 .

Sedangkan bagian sub sektor perikanan primer menunjukkan kecenderungan yang berbeda perikanan laut dengan perikanan darat. Perikanan laut mengalami penurunan angka pengganda output sejak tahun 1990 hingga 1995, dan kemudian menurun kembali pada tahun 2000 dan 2005, yaitu berturut-turut sebesar 1,665; 1,367; 1,323; dan 1,241. Sebaliknya untuk pengganda output perikanan darat sebesar 1,388 pada tahun 1990 turun menjadi sebesar 1,193 pada tahun 1995, namun kemudian meningkat menjadi sebesar 1,281 pada tahun 2000 dan sebesar 1,304 pada tahun 2005.

Berdasarkan perbandingan nilai angka pengganda untuk setiap tahunnya (1990, 1995, 2000 dan 2005), secara relatif sub sektor perikanan sekunder memiliki peran yang lebih besar dalam pembentukan output dibandingkan sub sektor perikanan primer. Selanjutnya bila hal yang sama diberlakukan untuk masing-masing bagian dari sub sektor perikanan primer maupun sub sektor perikanan sekunder, ternyata secara relatif perikanan laut dengan angka pengganda pendapatan masing-masing sebesar 1,665; 1,$367 ; 1,323$; dan 1,241 , mempunyai peran yang lebih besar dalam pembentukan output dibandingkan perikanan darat dengan angka pengganda masing-masing sebesar 1,388; 1,$193 ; 1,281$; dan 1,304; dan industri pengolahan dan pengawetan ikan dengan angka pengganda pendapatan masingmasing sebesar 3,$226 ; 2,125 ; 2,152$; dan 1,565 , mempunyai peran lebih besar dalam pembentukan output dibandingkan industri pengeringan dan penggaraman ikan dengan angka pengganda pendapatan masingmasing sebesar 2,$106 ; 1,736 ; 1,881$; dan 2,521 .

\section{Peran Sektor Perikanan dalam Pendapatan Rumah Tangga}

Dari Tabel 5 dan Gambar 2 terlihat bahwa besaran nilai angka pengganda pendapatan rumah tangga dari rata-rata keseluruhan sektor selama periode pengamatan (19902005) mengalami kecenderungan yang meningkat. Pada periode 1990-1995 dan 1995-2000 masing-masing meningkat sebesar $22,22 \%$ dan $0,96 \%$ dengan angka pengganda pendapatan rumah tangga sebesar 0,171 pada tahun 1990, sebesar 0,209 pada tahun 1995, sebesar 0,211 pada tahun 2000. Besaran angka pengganda pendapatan rumah tangga pada periode tersebut relatif sama. Namun pada periode selanjutnya (2005) angka pengganda tersebut meningkat sangat tajam hingga mencapai sebesar 839,81 dengan angka pengganda sebesar 1,983. Sedangkan untuk sektor perikanan, besarnya angka pengganda tersebut pada periode ESDKP (1990-1995) menurun sebesar $2,50 \%$, yaitu dari 1,197 pada tahun 1990 menjadi 1,192 pada tahun 1995, kemudian pada periode ERDKP (1995-2000) meningkat sebesar $3,22 \%$ dengan angka pengganda sebesar 1,196 pada tahun 2000 , dan selanjutnya pada ETDKP (2000-2005) meningkat secara signifikan sebesar $1.071,73 \%$ dengan angka pengganda sebesar 2,393 pada tahun 2005.

Untuk keseluruhan sektor dalam perekonomian Indonesia, angka-angka pengganda tersebut berarti bahwa untuk 
setiap peningkatan sepuluh juta rupiah permintaan akhir akan menyebabkan peningkatan pendapatan rumah tangga sebesar 1,71 juta rupiah pada tahun 1990, sebesar 2,09 juta rupiah pada tahun 1995, sebesar 2,11 juta rupiah pada tahun 2000 dan sebesar 19,83 juta rupiah pada tahun 2005. Sedangkan untuk sektor perikanan, setiap peningkatan sepuluh juta rupiah permintaan akhir akan menyebabkan peningkatan pendapatan rumah tangga sebesar 11,97 juta rupiah pada tahun 1990 , sebesar 11,92 juta rupiah pada tahun 1995, sebesar 11,96 juta rupiah pada tahun 2000 dan sebesar 107,17 juta rupiah pada tahun 2005.

Peningkatan angka pengganda

Tabel5. Rataan Pengganda Pendapatan Rumah Tangga dari Sektor Perikanan dan Keseluruhan Sektor Ekonomi di Indonesia, Tahun 1990-2005.

Table 5. Average of Household Income Multiplier of the Fisheries and All Economic Sectors in Indonesia, at of 1990-2005.

\begin{tabular}{|c|c|c|c|c|c|c|c|}
\hline \multirow[b]{2}{*}{ Sektor/ Sectors } & \multicolumn{4}{|c|}{ Tahun/Year } & \multicolumn{3}{|c|}{ Perubahan (\%)/ Changes (\%) } \\
\hline & 1990 & 1995 & 2000 & 2005 & $\begin{array}{c}1990- \\
1995 \\
(E S D K P)\end{array}$ & $\begin{array}{c}1995- \\
2000 \\
(\text { ERDKP) }\end{array}$ & $\begin{array}{c}2000- \\
2005 \\
(\text { ETDKP) }\end{array}$ \\
\hline $\begin{array}{l}\text { 1. Perikanan primer/ } \\
\text { Primary sectors: }\end{array}$ & 0,188 & 0,181 & 0,185 & 1,248 & $-3,72$ & 2,21 & 574,59 \\
\hline $\begin{array}{l}\text { - Perikanan laut / } \\
\text { Marine fisheries }\end{array}$ & 0,191 & 0,208 & 0,205 & 1,226 & 8,90 & $-1,44$ & 498,05 \\
\hline $\begin{array}{l}\text { - Perikanan da rat/ } \\
\text { Inland fisheries }\end{array}$ & 0,185 & 0,153 & 0,165 & 1,270 & $-17,30$ & 7,84 & 669,70 \\
\hline $\begin{array}{l}\text { 2. Perikanan sekunderl } \\
\text { Secondary sectors: }\end{array}$ & 0,206 & 0,203 & 0,212 & 3,538 & $-1,27$ & 4,23 & $1.568,87$ \\
\hline $\begin{array}{l}\text { - Industri pengeringan } \\
\text { dan penggaraman } \\
\text { ikan/ } \\
\text { Dried and saltied fish } \\
\text { industries }\end{array}$ & 0,187 & 0,1867 & 0,203 & 4,497 & $-0,12$ & 8,69 & $2.115,27$ \\
\hline $\begin{array}{l}\text { - Industri pengolahan } \\
\text { dan pengawetan ikan/ } \\
\text { Processied and } \\
\text { preservied fish } \\
\text { industries }\end{array}$ & 0,224 & 0,220 & 0,221 & 2,580 & $-1,79$ & 0,45 & $1.067,42$ \\
\hline 3. Perikanan/ Fisheries*) & 0,197 & 0,192 & 0,196 & 2,393 & $-2,50$ & 3,22 & $1.071,73$ \\
\hline $\begin{array}{l}\text { 4. Keseluruhan sektor / } \\
\text { Total sectors }\end{array}$ & 0,171 & 0,209 & 0,211 & 1,983 & 22,22 & 0,96 & 839,81 \\
\hline
\end{tabular}

Sumber: Hasil Pengolahan Data Tabel Input Output Tahun 1990, 1995, 2000 dan 2005/

Sources: Processed Result of the Input Output Table at of 1990, 1995, 2000 and 2005

Keterangan/ Remaks:

$\mathrm{ESDKP}=$ Era sebelum berdiri Departemen Kelautan dan Perikanan/ Before standing Marine and Fisheries Department era

ERDKP = Era transisi berdiri Departemen Kelautan dan Perikanan/ Transition standing Marine and Fisheries Departmentera

ETDKP = Era setelah berdiri Departemen Kelautan dan Perikanan/ After standing Marine and Fisheries Department era

*) Rataan angka pengganda dari perikanan primer dan perikanan sekunder/ Average of primary and secondary fisheris multiplier

**) Rataan angka pengganda dari seluruh sektor (hasil penghitungan selengkapnya tertera pada Lampiran Tabel 5, 6, 7 dan 8)/ Average of total sector multiplier (completed calculating yield at Apendix of Tables 5, 6, 7 and 8) 


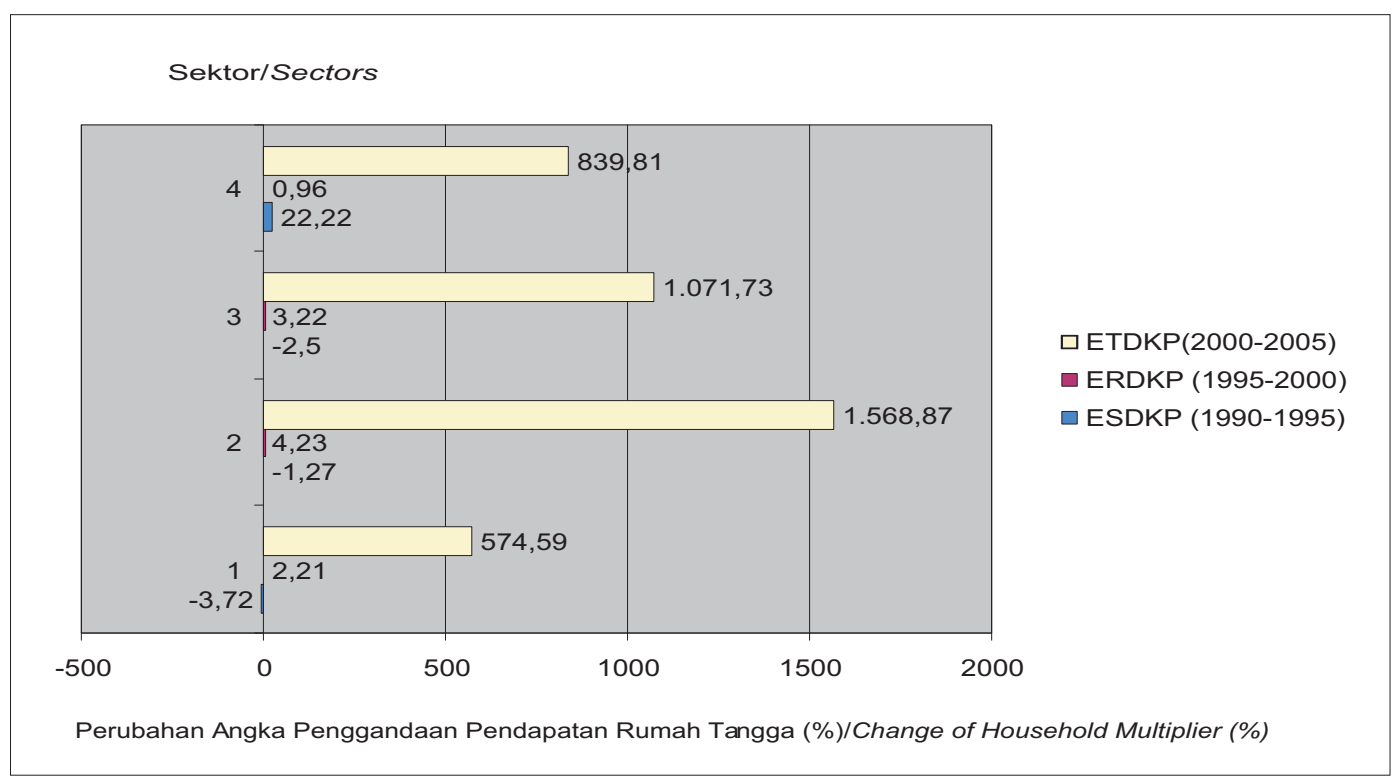

Gambar 2. Dinamika Perubahan Angka Pengganda Pendapatan Rumah Tangga dari Sektor Perikanan Indonesia, Selama ESDKP (1990-1995), ERDKP (1995-2000) dan ETDKP (2000-2005).

Figure 2. Dynamic Change of Household Income Multplier from the Indonesia Fisheries Sector During ESDKP (1990-1995), ERDKP(1995-2000) and ETDKP (2000-2005).

Keterangan/Remarks

$(1)=$ Sub sektor perikanan primer (perikanan tangkap laut dan perikanan budidaya)/Primary fisheries sector (marine capture and aquaculture fisheries)

(2) = Sub sektor perikanan sekunder (industri pengeringan dan penggaraman ikan dan industri pengolahan dan pengawetan ikan)/Secondary fisheries sector (drying and salting processing and preserving)

(3) = Rataan sektor perikanan (perikanan primer dan perikanan sekunder)/Avarage of fisheries sector(primary fisheries and secondary fisheries)

(4) = Rataan keseluruhan sektor dan perekonomian Indonesia/ Avarage of all sectors in Indonesian economy.

pendapatan rumah tangga yang terjadi sejak 1990 hingga 1995 sebesar $22,2 \%$, mengindikasikan adanya dampak positif dari peningkatan permintaan akhir (konsumsi rumah tangga, investasi, pengeluaran pemerintah dan ekspor) dalam mendorong peningkatan output dan pertumbuhan ekonomi secara nasional. Namun kemudian pada periode 1995-2000 peningkatan tersebut mengalami perlambatan hingga menjadi sebesar $0,96 \%$. Perlambatan tersebut diduga karena pada periode tersebut (1995-2000) perekonomian Indonesia masih menghadapi dampak negatif setelah mengalami tekanan akibat krisis ekonomi dan baru masuk dalam era pemulihan ekonomi pada pertengahan tahun 1997. Sedangkan pada periode 20002005, angka pengganda pendapatan rumah tangga tersebut mengalami peningkatan yang sangat signifikan hingga mencapai $839,81 \%$. Signifkansi peningkatan tersebut diduga karena pada periode 2000-2005, perekonomian Indonesia telah memasuki era pemulihan dan mulai merasakan manfaat berbagai kebijakan dan program pemulihan yang telah berjalan secara efektif. 
Kecenderungan yang serupa (dengan rata-rata keseluruhan sektor) terjadi untuk sub sektor perikanan primer dan sub sektor perikanan sekunder, namun terdapat sedikit perbedaan karena diawali dengan kecenderungan penurunan angka pengganda rumah tangga pada periode 1990-1995 dan kemudian meningkat pada periode selanjutnya (1995-2000 dan 2000-2005). Pada periode 1990-1995, angka pengganda pendapatan rumah tangga sub sektor perikanan primer dan sub sektor perikanan sekunder masing-masing sebesar 3,72\% dan $1,27 \%$. Pada periode 1995-2000, sub sektor perikanan primer dan sub sektor perikanan sekunder masing-masing meningkat sebesar $2,21 \%$ dan $4,23 \%$. Selanjutnya pada periode 2000-2005 angka pengganda ini meningkat sangat besar, yaitu masing-masing menjadi sebesar $574,59 \%$ dan $1.568,87 \%$. Perbedaan kecenderungan tersebut, diduga karena kedua sub sektor tersebut pada era krisis ekonomi justru memberikan tingkat pertumbuhan yang positif dan mengalami surplus yang besar dalam neraca perdagangannya.

Secara relatif nilai pengganda pendapatan rumah tangga untuk masingmasing bagian sub sektor perikanan lebih besar dibandingkan masing-masing bagian sub sektor industri pengolahan hasil perikanan. Nilai angka pengganda pendapatan rumah tangga dari kedua sub sektor tersebut, masing-masing sebesar 0,188 dan 0,206 pada tahun 1990 mengalami penurunan meskipun dalam kisaran yang relatif sempit yaitu masing-masing menjadi sebesar 0,181 dan 0,203. Kemudian pada tahun 2000, masing-masing mengalami peningkatan menjadi sebesar 0,185 dan 0,212; dan pada tahun 2005 masing-masing meningkat menjadi sebesar 1,248 dan 3,538. Dengan demikian, dari nilai angka pengganda pendapatan rumah tangga pada setiap tahun, seperti diuraikan di atas, diketahui bahwa untuk sub sektor perikanan primer ternyata perikanan laut mempunyai peran lebih besar dalam peningkatan pendapatan rumah tangga dibandingkan perikanan darat. Sedangkan untuk sub sektor perikanan sekunder, ternyata industri pengolahan dan pengawetan ikan mempunyai peran yang lebih besar dalam peningkatan pendapatan rumah tangga dibandingkan industri pengeringan dan penggaraman ikan.

\section{Peran Sektor Perikanan dalam Penyerapan Tenaga Kerja}

Dalam kaitan dengan pengangguran yang semakin meningkat saat ini, sektor yang memiliki pengganda penyerapan tenaga kerja yang besar perlu mendapat perhatian. Dari Tabel 6 dan Gambar 3, dapat diamati bahwa pengganda penyerapan tenaga kerja rata-rata dari keseluruhan sektor dalam perekonomian Indonesia menunjukkan kecenderungan penurunan selama kurun waktu 1990-2000. Namun sebaliknya pada kurun waktu selama 2000-2005 justru menunjukkan kecenderungan peningkatan angka pengganda tenaga kerja. Untuk rata-rata keseluruhan sektor dalam perekonomian, penurunan angka pengganda penyerapan tenaga kerja pada selang waktu periode tahun 1990 hingga 1995 sebesar 56,23\%, yaitu dari nilai angka pengganda penyerapan tenaga kerja sebesar 0,329 menjadi sebesar 0,144. Selanjutnya pada periode tahun 1995 hingga 2000 , penurunan angka pengganda tersebut semakin besar lagi sebesar $61,66 \%$, yaitu dari sebesar 0,144 menjadi sebesar 0,055. Namun pada periode tahun 2000 hingga 2005 justru terjadi peningkatan angka pengganda tenaga kerja yang signifikan sebesar $5.274,55 \%$, yaitu dari angka pengganda tenaga kerja sebesar 0,055 meningkat menjadi sebesar 2,956.

Kecenderungan yang sama seperti untuk keseluruhan sektor terjadi pula untuk sektor perikanan. Pada periode ESDKP (1990-1995) angka pengganda penyerapan tenaga kerja di sektor perikanan menurun sebesar $57,03 \%$, yaitu dari sebesar 0,272 pada tahun 1990 menjadi sebesar 0,107 pada tahun 1995 . Selanjutnya angka pengganda tersebut 
menurun lagi sebesar $62,83 \%$ pada periode ERDKP (1995-2000), yaitu dari sebesar 0,107 pada tahun 1995 menjadi sebesar 0,040 pada tahun 2000. Namun kemudian pada periode ETDKP (2000-2005), angka pengganda penyerapan tenaga kerja tersebut meningkat secara signifikan sebesar $9.572,81 \%$, yaitu dari angka pengganda sebesar 0,040 pada tahun 2000 menjadi sebesar 3,482 pada tahun 2005 (Tabel 6 dan Gambar 3).

Berdasarkan angka-angka pengganda penyerapan tenaga kerja tersebut, untuk rata-

Tabel 6. Rataan Pengganda Penyerapan Tenaga Kerja dari Sektor Perikanan Keseluruhan Sektor Ekonomi di Indonesia Tahun 1990-2005.

Table 6. Avarage of Labor Absoption Multiplier of the Fisheries and all Economiic Sector in Indonesia at of 1990-2005

\begin{tabular}{|c|c|c|c|c|c|c|c|}
\hline \multirow{2}{*}{ Sektor/ Sectors } & \multicolumn{4}{|c|}{ Tahun/Year } & \multicolumn{3}{|c|}{ Perubahan (\%)/ Changes (\%) } \\
\hline & 1990 & 1995 & 2000 & 2005 & $\begin{array}{c}1990- \\
1995 \\
\text { (ESDKP) }\end{array}$ & $\begin{array}{c}1995- \\
2000 \\
\text { (ERDKP) }\end{array}$ & $\begin{array}{c}2000-2005 \\
\text { (ETDKP) }\end{array}$ \\
\hline $\begin{array}{l}\text { 1. Perikanan primer/ } \\
\text { Primary sectors: }\end{array}$ & 0,371 & 0,122 & 0,045 & 1,285 & $-67,12$ & $-63,37$ & $2.787,64$ \\
\hline $\begin{array}{l}\text { - Perikanan laut / } \\
\text { Marine fisheries }\end{array}$ & 0,486 & 0,153 & 0,045 & 1,456 & $-68,52$ & $-70,59$ & $3.135,57$ \\
\hline $\begin{array}{l}\text { - Perikanan darat/ } \\
\text { Inland fisheries }\end{array}$ & 0,256 & 0,090 & 0,044 & 1,114 & $-64,84$ & $-51,11$ & $2.431,82$ \\
\hline $\begin{array}{l}\text { 2. Perikanan sekunderl } \\
\text { Secondary sectors: }\end{array}$ & 0,172 & 0,092 & 0,035 & 5,678 & $-46,80$ & $-62,30$ & $1.6357,97$ \\
\hline $\begin{array}{l}\text { - Industri pengeringan } \\
\text { dan penggaraman } \\
\text { ikan/ } \\
\text { Drying and salting } \\
\text { fish industries }\end{array}$ & 0,255 & 0,071 & 0,030 & 7,954 & $-72,16$ & $-57,75$ & $26.413,33$ \\
\hline $\begin{array}{l}\text { - Industri pengolahan } \\
\text { dan pengawetan } \\
\text { ikan/ } \\
\text { Processing and } \\
\text { preserving fish } \\
\text { industries }\end{array}$ & 0,089 & 0,112 & 0,039 & 3,402 & 25,84 & $-65,18$ & $8.623,08$ \\
\hline 3. Perikanan/ Fisheries*) & 0,272 & 0,107 & 0,040 & 3,482 & $-57,03$ & $-62,83$ & $9.572,81$ \\
\hline $\begin{array}{l}\text { 4. Keseluruhan sektor / } \\
\text { Total sectors }\end{array}$ & 0,329 & 0,144 & 0,055 & 2,956 & $-56,23$ & $-61,81$ & $5.274,55$ \\
\hline
\end{tabular}

Sumber: Hasil Pengolahan Data Tabel Input Output Tahun 1990, 1995, 2000 dan 2005/

Sources: Processed Result of the Input Output Table at of 1990, 1995, 2000 and 2005

Keterangan/ Remaks:

ESDKP = Era sebelum berdiri Departemen Kelautan dan Perikanan/ Before standing Marine and Fisheries Department era

ERDKP = Era transisi berdiri Departemen Kelautan dan Perikanan/ Transition standing Marine and Fisheries Department era

ETDKP = Era setelah berdiri Departemen Kelautan dan Perikanan/ After standing Marine and Fisheries Department era

*) Rataan angka pengganda dari perikanan primer dan perikanan sekunder/ Average of primary and secondary fisheris multiplier

**) Rataan angka pengganda dari seluruh sektor (hasil penghitungan selengkapnya tertera pada Lampiran Tabel 5, 6, 7 dan 8)/ Average of total sector multiplier (completed calculating yield at Apendix of Tables 5, 6, 7 and 8) 


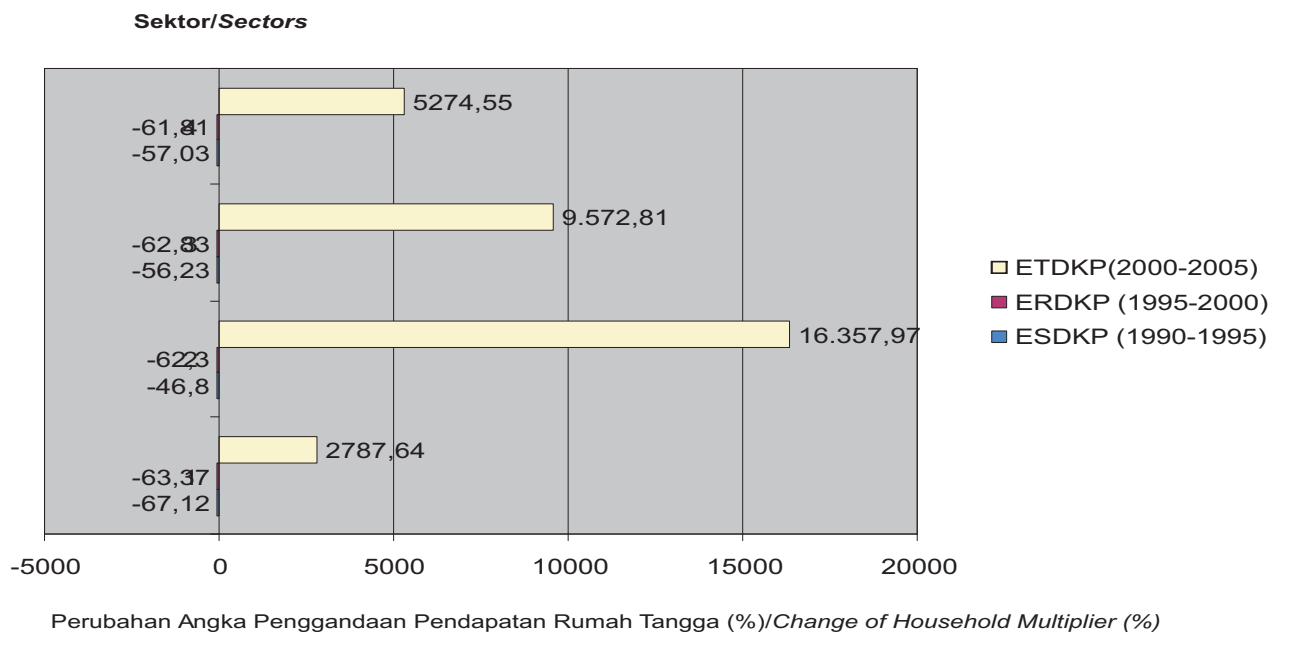

Gambar 3. Dinamika Perubahan Angka Pengganda Penyerapan Tenaga Kerja Sektor Perikanan Indonesia, Selama ESDKP (1990-1995), ERDKP (1995-2000) dan ETDKP (2000-2005).

Figure 3. Dynamic Change of Labor Absoption Multiplier of the Indonesia Fisheries Sector, During ESDKP (1990-1995), ERDKP(1995-2000) and ETDKP(2000-2005).

Keterangan/Remarks

$(1)=$ Sub sektor perikanan primer (perikanan tangkap laut dan perikanan budidaya)/Primary fisheries sector (marine capture and aquaculture fisheries)

$(2)=$ Sub sektor perikanan sekunder (industri pengeringan dan penggaraman ikan dan industri pengolahan dan pengawetan ikan)/Secondary fisheries sector (drying and salting processing and preserving)

$(3)=$ Rataan sektor perikanan (perikanan primer dan perikanan sekunder)/Average of fisheries sector(primary fisheries and secondary fisheries)

$(4)=$ Rataan keseluruhan sektor dan perekonomian Indonesia/ Average of all sectors in Indonesian economy.

rata keseluruhan sektor dalam perekonomian Indonesia berarti bahwa untuk setiap peningkatan seratus juta rupiah permintaan akhir akan menyebabkan peningkatan penyerapan tenaga kerja sebanyak 30 orang pada tahun 1990, sebanyak 14 orang pada tahun 1995, sebanyak 5 orang pada tahun 2000 dan sebanyak 29 orang pada tahun 2005. Sedangkan untuk sektor perikanan, setiap peningkatan seratus juta rupiah permintaan akhir akan menyebabkan peningkatan penyerapan tenaga kerja sebanyak 27 orang pada tahun 1990, sebanyak 10 orang pada tahun 1995, sebanyak 4 orang pada tahun 2000 dan sebesar 348 orang pada tahun 2005.

Penurunan angka pengganda penyerapan tenaga kerja baik untuk rata-rata keseluruhan sektor maupun untuk sektor perikanan dalam perekonomian Indonesia pada periode 1990-1995 dan 1995-2000 tersebut mengindikasikan semakin menurunnya kemampuan rata-rata keseluruhan sektor termasuk di sektor perikanan dalam perekonomian untuk menyerap tenaga kerja. Turunnya 
kemampuan tersebut diduga disebabkan oleh pengembangan lapangan usaha yang kurang mengandalkan sumberdaya lokal (foot-lose industry) dan cenderung padat modal, sehingga menjadi kurang memberikan tambahan penyerapan tenaga kerja secara berarti. Kondisi sebaliknya justru terjadi pada periode 2000-2005 dimana angka pengganda tersebut yang meningkat secara signifikan dibandingkan kedua periode sebelumnya. Namun secara relatif, pada periode 2000-2005 kemampuan sektor perikanan masih lebih baik dalam menyerap tenaga kerja dibandingkan dengan rata-rata keseluruhan sektor dalam perekonomian Indonesia.

Kecenderungan (pola perubahan) yang serupa dengan sektor perikanan selama periode pengamatan juga terjadi untuk sub sektor perikanan primer dan sub sektor perikanan sekunder. Pada sub sektor perikanan primer, nilai angka pengganda penyerapan tenaga kerjanya turun sebesar $67,12 \%$ selama periode $1990-1995$ dan turun lagi sebesar $63,37 \%$ selama periode $1995-$ 2000, atau dengan angka pengganda sebesar 0,371 pada tahun 1990 turun menjadi sebesar 0,122 pada tahun 1995 , dan terus menurun hingga menjadi sebesar 0,045 pada tahun 2000. Namun kemudian, pada periode 20002005, nilai angka pengganda penyerapan tenaga kerja tersebut mengalami peningkatan yang siginifikan dibandingkan periode sebelumnya, yaitu sebesar $2.787,64 \%$, atau dengan angka pengganda sebesar 0,045 pada tahun 2000 meningkat menjadi sebesar 1,285 pada tahun 2005. Angka-angka pengganda penyerapan tenaga kerja tersebut berarti bahwa setiap peningkatan seratus juta permintaan akhir di sub sektor perikanan primer akan menyebabkan peningkatan penyerapan tenaga kerja total sebanyak 37 orang pada tahun 1990, sebanyak 12 orang pada tahun 1995, sebanyak 4 orang pada tahun 2000 dan sebanyak 278 orang.

Demikian pula untuk sub sektor perikanan sekunder, nilai angka pengganda penyerapan tenaga kerjanya turun sebesar
$46,80 \%$ pada periode $1990-1995$, yaitu dari angka pengganda sebesar 0,172 pada tahun 1990 menjadi sebesar 0,092 pada tahun 1995, dan kemudian menurun lagi hingga sebesar $62,30 \%$ pada periode $1995-2000$, yaitu dari angka pengganda menjadi sebesar 0,035 pada tahun 2000. Setelah dua periode (19901995 dan 1995-2000) angka pengganda tersebut mengalami penurunan, maka sejak tahun 2000-2005 justru menunjukkan kecenderungan yang meningkat secara signifikan sebesar $1.6357,97 \%$, yaitu dari angka pengganda sebesar 0,035 pada tahun 2000 menjadi sebesar 5,678 pada tahun 2005 . Dari besaran nilai-nilai angka pengganda tersebut, berarti bahwa setiap peningkatan seratus juta rupiah permintaan akhir di sub sektor perikanan sekunder akan menyebabkan peningkatan penyerapan tenaga kerja total sebanyak 17 orang pada tahun 1990, sebanyak 9 orang pada tahun 1995, sebanyak 3 orang pada tahun 2000 dan sebanyak 163 orang pada tahun 2005.

Selanjutnya bila dilihat pada level bagian dari sub sektor perikanan primer dan sub sektor perikanan sekunder pada setiap tahun yang diamati, nilai pengganda tenaga kerja untuk masing-masing bagian sub sektor perikanan primer (perikanan laut dan perikanan darat) lebih besar dibandingkan pengganda penyerapan tenaga kerja untuk masing-masing bagian sub sektor perikanan sekunder (industri pengeringan dan penggaraman ikan dan industri pengolahan dan pengawetan ikan). Dengan kata lain, selama periode pengamatan sub sektor perikanan mempunyai peran yang lebih besar dalam penyerapan tenaga kerja dibandingkan sub sektor perikanan sekunder. Secara relatif untuk setiap tahun yang diamati, perikanan laut dengan angka pengganda tenaga kerja masing-masing sebesar 0,486; 0,153; 0,054; dan 1,456, mempunyai peran lebih besar dalam penyerapan tenaga kerja dibandingkan perikanan darat dengan angka pengganda masing-masing sebesar 0,256; 0,090; 0,044; dan 1,114. Sedangkan industri pengolahan 
dan pengawetan ikan dengan koefisien pengganda tenaga kerja masing-masing sebesar 0,$255 ; 0,071 ; 0,030 ; 7,954$, mempunyai peran yang lebih besar dalam penyerapan tenaga kerja dibandingkan industri pengeringan dan penggaraman ikan dengan angka pengganda penyerapan tenaga masing-masing sebesar 0,089; 0,112; 0,039; dan 3,402.

\section{KESIMPULAN DAN IMPLIKASI KEBIJAKAN}

\section{Kesimpulan}

1. Peran sektor perikanan dalam pembentukan output perekonomian Indonesia menunjukkan kecenderungan penurunan pada era sebelum dan setelah berdiri Departemen Kelautan dan Perikanan (1990-1995 dan 2000-2005). Pada era transisi (1995-2000) justru menunjukkan kecenderungan peningkatan perannya dalam pembentukan output tersebut. Pembentukan DKP relatif belum mampu meningkatkan peran sektor perikanan dalam pembentukan output perekonomian Indonesia. Berdasarkan perbandingan nilai angka pengganda outputnya, secara relatif selama periode pengamatan sub sektor perikanan sekunder memiliki peran yang lebih besar dalam pembentukan output total dibandingkan sub sektor perikanan primer. Untuk sub sektor perikanan primer maupun sub sektor perikanan sekunder, ternyata secara relatif perikanan laut mempunyai peran yang lebih besar dalam pembentukan output dibandingkan perikanan darat. Industri pengolahan dan pengawetan ikan mempunyai peran lebih besar dalam pembentukan output dibandingkan industri pengeringan dan penggaraman ikan.

2. Peran sektor perikanan dalam peningkatan pendapatan rumah tangga di Indonesia menunjukkan kecenderungan yang meningkat pada era transisi dan setelah berdiri Departemen Kelautan dan Perikanan. Bila dibandingkan dengan rataan keseluruhan sektor dalam perekonomian Indonesia, kecenderungan tersebut ternyata lebih tinggi dan mengindikasikan bahwa pembentukan DKP telah mampu meningkatkan perannya dalam pendapatan rumah tangga di Indonesia. Secara relatif peran sub sektor perikanan primer lebih besar dibandingkan sub sektor sekunder. Untuk sub sektor perikanan primer, perikanan laut memegang peranan lebih besar dalam peningkatan pendapatan rumah tangga dibandingkan perikanan darat. Sedangkan untuk sub sektor perikanan sekunder, industri pengolahan dan pengawetan ikan mempunyai peran yang lebih besar dalam peningkatan pendapatan rumah tangga dibandingkan industri pengeringan dan penggaraman ikan.

3. Berdasarkan dinamika angka pengganda penyerapan tenaga kerja, peran sektor perikanan dalam penyerapan tenaga kerja di Indonesia menunjukkan kecenderungan peningkatan pada era setelah berdiri DKP. Kecenderungan ini ternyata lebih tinggi dibandingkan rata-rata keseluruhan sektor dalam perokomian Indonesia. Pada era sebelum dan transisi berdiri DKP menunjukkan kecenderungan penurunan perannya dalam penyerapan tenaga kerja tersebut. Nampak bahwa pembentukan DKP telah mampu meningkatkan perannya dalam penyerapan tenaga kerja di Indonesia. Secara relatif sub sektor perikanan primer mempunyai peran yang lebih besar dalam penyerapan tenaga kerja dibandingkan sub sektor perikanan sekunder. Untuk sub sektor perikanan primer, perikanan laut mempunyai peran lebih besar dibandingkan perikanan darat. Sedangkan untuk industri pengolahan dan pengawetan ikan mempunyai peran yang lebih besar dalam penyerapan tenaga kerja dibandingkan industri pengeringan dan penggaraman ikan. 


\section{Implikasi Kebijakan}

Dari kecenderungan perubahan pengganda output, pengganda pendapatan dan pengganda tenaga kerja, secara implisit mengindikasikan telah terjadi perubahan dalam proses produksi baik di sub sektor perikanan maupun sub sektor industri pengolahan hasil perikanan, terutama dari sektor usaha tradisional ke usaha relatif modern. Transformasi penggunaan faktor produksi tersebut bergerak ke arah peningkatan penggunaan faktor produksi yang padat modal sebagai upaya mengganti ketergantungan terhadap tenaga kerja manusia, seperti ditunjukkan oleh relatif tingginya peranan perikanan laut dibanding perikanan darat; atau tingginya peranan industri pengolahan dan pengawetan ikan dibanding industri pengeringan dan penggaraman ikan. Dari sisi mikro (pengusaha), perubahan tersebut dapat dipandang sebagai hasil dari pilihan kebijakan atau keputusan yang rasional. Namun demikian pilihan tersebut berdampak kurang menguntungkan dari sisi makro, karena menyebabkan permasalahan pengangguran di Indonesia menjadi semakin kompleks.

Kecenderungan proses transformasi struktural juga telah terjadi dari sub sektor perikanan primer ke arah perikanan sekunder yang ditunjukkan oleh eksistensi industri pengolahan hasil perikanan. Mengingat dominasi peran kesempatan kerja di sub sektor perikanan primer, maka pengembangan perikanan sekunder pada masa mendatang masih perlu memprioritaskan pengembangan keterkaitan dengan sub sektor perikanan primer. Penerapan paradigma pembangunan yang mengintegrasikan secara vertikal antara sub sektor perikanan primer dengan perikanan sekunder perlu mendapatkan penanganan dan prioritas di masa yang akan datang.

Pengembangan industri pengolahan hasil perikanan (perikanan sekunder) perlu diarahkan agar dapat berperan sebagai lokomotif bagi pertumbuhan ekonomi sub sektor perikanan primer (perikanan laut dan perikanan darat) dan secara sinergis agar mampu meningkatkan perannya dalam perekonomian Indonesia. Fokus kebijakan hendaknya dapat meningkatkan produktivitas sektor perikanan primer melalui upaya pengelolaan dan pemanfaatan potensi sumberdaya secara optimal, dan mendorong pengembangan industri pengolahan hasil perikanan yang berskala kecil dan menengah, seperti industri pengeringan dan penggaraman ikan serta biota perairan lainnya.

\section{DAFTAR PUSTAKA}

Biro Pusat Statistik (BPS). 1990. Tabel InputOutput Indonesia 1990. Jilid I, II dan III. Biro Pusat Statistik. Jakarta.

Biro Pusat Statistik (BPS). 1999. Tabel InputOutput Indonesia 1995. Jilid I, II dan III. Biro Pusat Statistik. Jakarta.

Badan Pusat Statistik (BPS). 2004. Tabel Input-Output Indonesia 2000. Jilid I, II dan III. Badan Pusat Statistik. Jakarta.

Badan Pusat Statistik (BPS). 2007. Tabel Input-Output Indonesia 2005. Jilid I, II dan III. Badan Pusat Statistik. Jakarta.

Badan Pusat Statistik (BPS). 2001. Statistik Indonesia, 2000. Badan Pusat Statistik. Jakarta.

Badan Pusat Statistik (BPS). 2002. Statistik Indonesia, 2001. Badan Pusat Statistik. Jakarta.

Badan Pusat Statistik (BPS). 2003. Statistik Indonesia, 2002. Badan Pusat Statistik. Jakarta.

Badan Pusat Statistik (BPS). 2004. Statistik Indonesia, 2003. Badan Pusat Statistik. Jakarta.

Badan Pusat Statistik (BPS). 2005. Statistik Indonesia, 2004. Badan Pusat Statistik. Jakarta.

Badan Pusat Statistik (BPS). 2006. Statistik Indonesia, 2005. Badan Pusat Statistik. Jakarta.

Dahuri, R., Rais I., Ginting, S.P., dan Sitepu, M.J. 2001. Pengelolaan Sumberdaya 
Wilayah Pesisir dan Lautan Secara Terpadu. Cetakan Kedua, Edisi Revisi.PT. Praduya Paramita. Jakarta.

Departemen Kelautan dan Perikanan (DKP). 2005a. Scinetific Justification Petetapan Sasaran Makro Pembangunan Sektor kelautan dan Perikanan Tahun 2007. Departemen Kelautan dan Perikanan. Jakarta.

Departemen Kelautan dan Perikanan (DKP). 2005b. Pelaksanaan Pembangunan Kelautan dan Perikanan dalam Satu Tahun Kabinet Indonesia Bersatu. Departemen Kelautan dan Perikanan. Jakarta.

Kusumastanto, T. 2001. An Evaluation of Investment Strategy for the Development of Brackish Shrimp Aquaculture Industry in Indonesia. Jurnal Teknologi Perikanan dan Kelautan. Vol. 1 No. 4.1-28.

Kusumastanto, T. 2002. Reposisi "Ocean Policy" dalam Pembangunan Ekonomi Indonesia di Era Otonomi Daerah. Orasi IImiah: Guru Besar tetap Bidang IImu kebijakan Ekonomi Perikanan dan Kelautan, Fakultas Perikanan dan IImu Kelautan, Institut Pertanian Bogor 21 Sepetember 2002. Institut Pertanian Bogor. Bogor. 134 halaman.
Miller, E.R. and Blair, D.P. 1985. Input-Ouput Analysis: Foundations and Extentions. Precentice Hall Inc, $464 \mathrm{pp}$.

Nazara, S. 2005. Analisis Input Output. Lembaga Penerbit Fakultas Ekonomi Universitas Indonesia. Jakarta. 130 halaman.

Perserikatan Bangsa-Bangsa (PBB). 2007. Studi Dalam Metode: Tabel Input-Output dan Analisis. Seri F No. 14, Rev 2. Penerjemah: Soeheba Kramadibrata dan Sri Edi Swasono; Pendamping: Rudiansyah. Universitas Indonesia Press. Universitas Indonesia, Jakarta. 265 halaman.

West, G.R. 1992. Input-Output Analysis for Practitioners. Departement of Economic. University of Queensland, P: 39-67. 
Lampiran/Appendix

Tabel7. Penggandan Output, Pengganda Pendapatan Rumah Tangga dan Pengganda Penyerapan Tenaga Kerja, Tahun 1990.

Table 7. Output, Household Income and Labor Absoption Multipliers, at of 1990.

\begin{tabular}{|c|c|c|c|c|}
\hline \multirow{2}{*}{ Sektor/Sectors } & \multirow[b]{2}{*}{$\begin{array}{l}\text { Kode/ } \\
\text { Code }\end{array}$} & \multicolumn{3}{|c|}{$\begin{array}{l}\text { Koefisien Pengganda/ } \\
\text { Coefficient of Multiplier }\end{array}$} \\
\hline & & $\begin{array}{l}\text { Output/ } \\
\text { Output }\end{array}$ & $\begin{array}{l}\text { Pendapatan/ } \\
\text { Income }\end{array}$ & $\begin{array}{c}\text { Tenaga } \\
\text { Kerja/ Labor }\end{array}$ \\
\hline $\begin{array}{l}\text { Pertanian non perikanan/ Agriculture non } \\
\text { fisheries }\end{array}$ & 1 & 1,04702 & 0,02230 & 0,10879 \\
\hline $\begin{array}{l}\text { Perikanan laut dan hasil perairan laut } \\
\text { lainnya/ Marine fisheries and its result }\end{array}$ & 2 & 1,66497 & 0,19135 & 0,48609 \\
\hline $\begin{array}{l}\text { Perikanan darat dan hasil perairan darat } \\
\text { lainnya/ Fresh water fisheries and its result }\end{array}$ & 3 & 1,38766 & 0,18546 & 0,25645 \\
\hline $\begin{array}{l}\text { Pertambangan dan penggalian/ Mining and } \\
\text { quarrying }\end{array}$ & 4 & 1,28727 & 0,10130 & 0,08937 \\
\hline $\begin{array}{l}\text { Industri pengeringan/penggaraman ikan/ } \\
\text { Drying and salting processing and Industries }\end{array}$ & 5 & 2,10613 & 0,18684 & 0,25458 \\
\hline $\begin{array}{l}\text { Industri pengolahan dan pengawetan ikan/ } \\
\text { Processing and preserving industries }\end{array}$ & 6 & 3,22624 & 0,22424 & 0,52316 \\
\hline $\begin{array}{l}\text { Industri pengolahan hasil perikanan non } \\
\text { perikanan/ Agriculture non fisheries } \\
\text { processing industries }\end{array}$ & 7 & 2,18922 & 0.15424 & 0,20994 \\
\hline Industri lainnya/ Other industries & 8 & 2,16631 & 0,16724 & 0,27999 \\
\hline Jasa dan lainnya/ Service and others & 9 & 2,05234 & 0,30607 & 0,75632 \\
\hline
\end{tabular}

Sumber: Hasil Pengolahan Data Tabel Input Output Tahun 1990.

Source: Data processing Input Output Table, 1990.

Tabel 8. Penggandan Output, Pengganda Pendapatan Rumah Tangga dan Pengganda Penyerapan Tenaga Kerja, Tahun 1995.

Table 8. Output, Household Income and Labor Absorption Multipliers, at of 1995.

\begin{tabular}{lccccr}
\hline \multicolumn{1}{c}{ Sektor/sectors } & Kode/ & \multicolumn{3}{c}{$\begin{array}{c}\text { Koefisien Pengganda/ } \\
\text { Coefficient of Multiplier }\end{array}$} \\
\cline { 3 - 6 } & Code & $\begin{array}{c}\text { Output/ } \\
\text { Output }\end{array}$ & $\begin{array}{c}\text { Pendapatan/ } \\
\text { Income }\end{array}$ & $\begin{array}{c}\text { Tenaga } \\
\text { Kerja/Labor }\end{array}$ \\
\hline $\begin{array}{l}\text { Pertanian non perikanan/ Agriculture non } \\
\text { fisheries }\end{array}$ & 1 & 1,27785 & 0,44397 & 0,44397 \\
$\begin{array}{l}\text { Perikanan laut dan hasil perairan laut } \\
\text { lainnya/ Marine fisheries and its result }\end{array}$ & 2 & 1,36708 & 0,15289 & 0,15289 \\
$\begin{array}{l}\text { Perikanan darat dan hasil perairan darat } \\
\text { lainnya/ Fresh water fisheries and its result }\end{array}$ & 3 & 1,19256 & 0,09032 & 0,09032 \\
$\begin{array}{l}\text { Pertambangan dan penggalian/ Mining and } \\
\text { quarrying }\end{array}$ & 4 & 1,19409 & 0,03047 & 0,03047 \\
$\begin{array}{l}\text { Industri pengeringan/Penggaraman ikan/ } \\
\text { Drying and salting processing and industries }\end{array}$ & 5 & 1,73622 & 0,07080 & 0,07080 \\
$\begin{array}{l}\text { Industri pengolahandan pengawetan ikan/Fish } \\
\text { processied and preservied industries }\end{array}$ & 6 & 2,12499 & 0,11219 & 0,11219 \\
\hline
\end{tabular}


Lanjutan Tabel 8/Continued Table 8

\begin{tabular}{|c|c|c|c|c|}
\hline \multirow{2}{*}{ Sektor/Sectors } & \multirow{2}{*}{$\begin{array}{l}\text { Kode/ } \\
\text { Code }\end{array}$} & \multicolumn{3}{|c|}{$\begin{array}{l}\text { Koefisien Pengganda/ } \\
\text { Coefficient of Multiplier }\end{array}$} \\
\hline & & $\begin{array}{l}\text { Output/ } \\
\text { Output }\end{array}$ & $\begin{array}{l}\text { Pendapatan/ } \\
\text { Income }\end{array}$ & $\begin{array}{c}\text { Tenaga } \\
\text { Kerja/Labor }\end{array}$ \\
\hline $\begin{array}{l}\text { Industri pengolahan hasil perikanan non } \\
\text { perikanan/ Agriculture non fisheries } \\
\text { processing industries }\end{array}$ & 7 & 1,90840 & 0,18268 & 0,18268 \\
\hline Industri lainnya/ Other industries & 8 & 1,62181 & 0,09378 & 0,09378 \\
\hline Jasa dan lainnya/ Service and others & 9 & 1,60296 & 0,12057 & 0,12057 \\
\hline
\end{tabular}

Sumber: Hasil Pengolahan Data Tabel Input Output Tahun 1990.

Source: Data Processing Input Output Table, 1990.

Tabel 9. Penggandan Output, Pengganda Pendapatan Rumah Tangga dan Pengganda Penyerapan Tenaga Kerja, Tahun 2000.

Table9. Output, Household Income and Labor Absoption Multipliers, at of 2000.

\begin{tabular}{|c|c|c|c|c|}
\hline \multirow{2}{*}{ Sektor/ Sectors } & \multirow{2}{*}{$\begin{array}{l}\text { Kodel } \\
\text { Code }\end{array}$} & \multicolumn{3}{|c|}{$\begin{array}{l}\text { Koefisiens Pengganda/ } \\
\text { Coefficient of Multiplier }\end{array}$} \\
\hline & & $\begin{array}{l}\text { Output/ } \\
\text { Output }\end{array}$ & $\begin{array}{l}\text { Pendapatan/ } \\
\text { Income }\end{array}$ & $\begin{array}{c}\text { Tenaga } \\
\text { Kerja/Labor }\end{array}$ \\
\hline $\begin{array}{l}\text { Pertanian non perikanan/ Agriculture non } \\
\text { fisheries }\end{array}$ & 1 & 1,33540 & 0,23463 & 0,18488 \\
\hline $\begin{array}{l}\text { Perikanan laut dan hasil perairan laut } \\
\text { lainnya/ Marine fisheries and its result }\end{array}$ & 2 & 1,32711 & 0,20497 & 0,04504 \\
\hline $\begin{array}{l}\text { Perikanan darat dan hasil perairan darat } \\
\text { lainnya/ Fresh water fisheries and its result }\end{array}$ & 3 & 1,28131 & 0,16517 & 0,04351 \\
\hline $\begin{array}{l}\text { Pertambangan dan penggalian/ Mining and } \\
\text { quarrying }\end{array}$ & 4 & 1,15845 & 0,15330 & 0,00696 \\
\hline $\begin{array}{l}\text { Industri pengeringan/penggaraman ikan/ } \\
\text { Drying and salting processing and industries }\end{array}$ & 5 & 1,88146 & 0,20339 & 0,02972 \\
\hline $\begin{array}{l}\text { Industri pengolahan dan pengawetan ikan/ } \\
\text { Processing and preserving industries }\end{array}$ & 6 & 2,15273 & 0,22088 & 0,03946 \\
\hline $\begin{array}{l}\text { Industri pengolahan hasil perikanan non } \\
\text { perikanan/ Agriculture non fisheries } \\
\text { processing industries }\end{array}$ & 7 & 1,85676 & 0,23827 & 0,06123 \\
\hline Industri lainnya/ Other industries & 8 & 1,59720 & 0,18505 & 0,03171 \\
\hline Jasa dan lainnya/ Service and others & 9 & 1,61518 & 0,29203 & 0,05498 \\
\hline
\end{tabular}

Sumber: Hasil Pengolahan Data Tabel Input Output Tahun 2000.

Source: DataProcessing Input Output Table, 2000. 
Tabel 10. Pengganda Output, Pengganda Pendapatan Rumah Tangga dan Pengganda Penyerapan Tenaga Kerja, Tahun 2005.

Table 10. Output, Household Income and Labor Absoption Multipliers, at of 2005

\begin{tabular}{|c|c|c|c|c|}
\hline \multirow{2}{*}{ Sektor/Sectors } & \multirow{2}{*}{$\begin{array}{l}\text { Kode/ } \\
\text { Code }\end{array}$} & \multicolumn{3}{|c|}{$\begin{array}{l}\text { Koefisiens Pengganda/ } \\
\text { Coefficient of Multiplier }\end{array}$} \\
\hline & & $\begin{array}{l}\text { Output/ } \\
\text { Output }\end{array}$ & $\begin{array}{l}\text { Pendapatan/ } \\
\text { Income }\end{array}$ & $\begin{array}{c}\text { Tenaga } \\
\text { Kerja/Labor }\end{array}$ \\
\hline $\begin{array}{l}\text { Pertanian non perikanan/ Agriculture non } \\
\text { fisheries }\end{array}$ & 1 & 1,36955 & 1,32730 & 1,10305 \\
\hline $\begin{array}{l}\text { Perikanan laut dan hasil perairan laut } \\
\text { lainnya/ Marine fisheries and its result }\end{array}$ & 2 & 1,24055 & 1,22593 & 1,45637 \\
\hline $\begin{array}{l}\text { Perikanan darat dan hasil perairan darat } \\
\text { lainnya/ Fresh water fisheries and its result }\end{array}$ & 3 & 1,30428 & 1,26999 & 1,11407 \\
\hline $\begin{array}{l}\text { Pertambangan dan penggalian/ Mining and } \\
\text { quarrying }\end{array}$ & 4 & 1,22383 & 1,28352 & 1,94977 \\
\hline $\begin{array}{l}\text { Industri pengeringan/penggaraman ikan/Fish } \\
\text { dried and saltied processied and industries }\end{array}$ & 5 & 2,52117 & 4,49689 & 7,95380 \\
\hline $\begin{array}{l}\text { Industri pengolahan dan pengawetan ikan/Fish } \\
\text { processied and preservied industries }\end{array}$ & 6 & 1,56454 & 2,57998 & 3,40194 \\
\hline $\begin{array}{l}\text { Industri pengolahan hasil perikanan non } \\
\text { perikanan/ Agriculture non fisheries } \\
\text { processing industries }\end{array}$ & 7 & 1,92691 & 2,38583 & 4,68114 \\
\hline Industri lainnya/ Other industries & 8 & 1,59411 & 1,74183 & 3,24280 \\
\hline Jasa dan lainnya/ Service and others & 9 & 1,67788 & 1,53364 & 1,70456 \\
\hline
\end{tabular}

Sumber: Hasil Pengolahan Data Tabel Input Output Tahun 2005.

Source: Data Processing Input Output Table, 2005. 